ReApers

Journal of Research in Psychology (JRP)

www. readersinsight.net/jrp

ISSN: 2664-9500 (Online)

ISSN: 2664-9497 (Print)

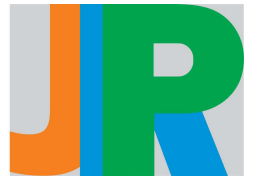

\title{
Incorporating Tarsia to Foster Student Collaboration in the Mathematics Classroom
}

\author{
Chua Ching Hao ${ }^{1 *}$, Azlina binti Mohd Kosnin² \\ ${ }^{1,2}$ School of Education, Faculty of Social Sciences and Humanities, UTM, Johor \\ ${ }^{1 *}$ Corresponding author: chinghao1990@graduate.utm.my \\ ${ }^{2}$ Corresponding author: p-azlina@utm.my
}

\begin{abstract}
It is evident that we will be able to retain and apply more knowledge into practice if we have spent more time in reviewing and practicing. Active student practice and consistent review are the key components of mastery learning. However, in Mathematics teaching, some of the commonly used instructional approaches such as "Practice on the blackboard" and "Assignment of homework" contradict the above mentioned key elements of content mastery. In view of this, our study aims to examine the effectiveness of an interactive activity, Tarsia. Tarsia allows students to elicit the characteristics of fun and playfulness while ensuring enough practices are obtained. Our results have shown that students view Tarsia as an interesting activity which enables them to develop new knowledge as well as promoting collaborative skills among the team members. Collaboration, is one of the four $21^{\text {st }}$ century skills proposed by National Education Association (NEA) as the important skills to possess in order to succeed in the constantly changing $21^{\text {st }}$ century.
\end{abstract}

Keywords: Collaborative Learning, Play-Based Learning, Playfulness, Tarsia, $21^{\text {st }}$ Century Skills.

\section{Article Information:}

Received: $20^{\text {th }}$, April 2019

Revised: $4^{\text {th }}$, Aug 2019

Accepted: $1^{\text {st }}$ Sep 2019

\section{Introduction}

In the realm of $21^{\text {st }}$ century digital world, National Education Association proposed Communication, Collaboration, Creativity, and Critical Thinking as the framework for $21^{\text {st }}$ century learning (NEA, 2014). Future workers need to be able think on their feet; they need to be able to scrutinize the argument, assess the validity of evidence, to determine the cause and effect of a particular event (Kivunja, 2014). In addition to that, living in a borderless globe of internet, future workers are expected to work with diverse group of people from different backgrounds. They are expected to articulate their ideas fluently, engage in active listening and be able to communicate through various medium. Collaboration is another essential skill that the future workers shall possess. They would be required to freely work with others from diverse background, as well as able to give and receive constructive feedback (Kivunja, 2014). It is unquestionable that communication and collaboration skills have become a determining attribute to succeed in the face of embracing Industrial Revolution (IR) 4.0 (Ananiadou \& Claro, 2009).

However, according to a study done by Fwu \& Wang, we have not yet done enough preparation to supply our students with these skills that they need to succeed in the future that awaits them. For example, in Mathematics teaching, most of the teachers are still using "practice on blackboard" method to review and check students' understanding on certain topics (Fwu \& Wang, 2006). Specifically, we have not provided young students enough opportunity to think critically, communicate effectively, converse creatively and collaborate thoroughly in the class. The traditional teacher-oriented instruction lacks of these elements (Roh, 2003). Thus, it is not surprising to say the students haven't been well prepared to embrace the $21^{\text {st }}$ century.

Practices is equally important in learning mathematics. Using repetitive tasks to improve students' fluency, speed, and accuracy has been long recognized as an important event to achieve learning objective (Watson \& Matson, 2004). In the world where the mainstream education is exam-oriented, we could not compromise the recognition of $21^{\text {st }}$ century skills over the academic performance.

In view of this, we would like to propose the incorporation of Tarsia as a mean to induce collaboration and communication among the students while maintaining the amount of practices and works which we want our students to have. Tarsia is a free licensed software developed by Hermitech Laboratory. User will be able to design customized jigsaws to fit into their teaching objective (Hermitech Laboratory). The goal of the activity is to assemble the puzzle so that a particular shape will be formed. Participants need to solve the question and match the answers which appear on another piece of card. This study aims to discover whether Tarsia can be used an interactive activity to foster students' collaboration in the Mathematics classroom.

\section{Methodology}

25 students from two different groups of the Monash University Foundation Year program from Sunway College Johor Bahru were used as the subjects of this study. The first group of students comprised 12 students and they used Tarsia as a revision tool to revise the topic of Probability. The second group of students consisted of 13 students and they used Tarsia to revise the topic of Business Mathematics.

For this research, sampling was collected through convenience sampling method. Results were collected by having the respondents to 
answer a questionnaire. The questionnaire used was The Collaborative Learning, Social presence, and Satisfaction (CLSS) questionnaire adapted by Sorden and So \& Brush (Sroden, 2011, p. 148, 149; So \& Brush, 2008). The computed Cronbach's alpha coefficient for this survey was 0.821. (See Appendix A for the CLSS questionnaire). Conbach's alpha is used to measure internal consistency of the questions. In our case, Cronbach's alpha value of 0.821 signifies that the questions asked in the questionnaire are reliable. This CLSS questionnaire was revamped to collected students' perceptions towards collaborative learning after Tarsia had been implemented as a revision tool.

This questionnaire consisted of 7 questions; it was constructed to measure students' satisfaction with collaborative learning. All students had given their permissions to be part of the study before the survey was implemented.

\section{Results and Discussion}

In this part, we present the summarized results and discuss their implications.

\begin{tabular}{|l|c|c|c|}
\hline \multicolumn{3}{|c|}{$\begin{array}{l}\text { Table 1: (CLSS) Questionnaire Items, Listed by Mean from } \\
\text { Highest to Lowest as They were Rated by Study Participants. }\end{array}$} \\
\hline \multicolumn{1}{|c|}{ Item Descriptions } & N & Mean & SD \\
\hline $\begin{array}{l}\text { 1. Overall, I am satisfied with my } \\
\text { collaborative learning experience in this } \\
\text { course. }\end{array}$ & 25 & 4.280 & 0.737 \\
\hline $\begin{array}{l}\text { 2. Collaborative learning in my group } \\
\text { was effective }\end{array}$ & 25 & 4.200 & 0.866 \\
\hline $\begin{array}{l}\text { 3. I felt part of a learning community in } \\
\text { my group. }\end{array}$ & 25 & 4.040 & 1.020 \\
\hline $\begin{array}{l}\text { 4. I actively exchanged my ideas with } \\
\text { group members. }\end{array}$ & 25 & 4.000 & 0.957 \\
\hline $\begin{array}{l}\text { 5. I was able to develop problem solving } \\
\text { skills through peer collaboration. }\end{array}$ & 25 & 3.880 & 1.013 \\
\hline $\begin{array}{l}\text { 6. I was able to develop new skills and } \\
\text { knowledge from other members in my } \\
\text { group. }\end{array}$ & 25 & 3.800 & 1.000 \\
\hline $\begin{array}{l}\text { 7. Collaborative learning in my group } \\
\text { was time consuming. }\end{array}$ & 25 & 2.120 & 1.236 \\
\hline
\end{tabular}

According to the results tabled in table 1 above, the highest rank item shows that students find Tarsia as an effective tool to improve their collaborative learning experience. Tarsia enables them to collaborate in an effective manner where they would feel as part of the team. Tarsia also allows them to exchange ideas with other group members effectively. From their above average mean value, it is also shown that Tarsia allows student to develop problem solving skills as well as new knowledge among their team members. Question 7 reflects students indulge themselves in Tarsia until they have lost the sense of time. This is, as defined by Csikszentmihalyi, the students have entered the state of flow, a hyper-focus state experienced by those who are fully engaged with their work, hobbies, or relationships (Csikszentmihályi,1990).

\section{Limitation and Further Study}

In this particular study, convenience sampling method was adopted. Future studies looking into the problem shall consider a probability sampling technique so that the yielded result can be the better representative of the entire population. This study looks into the effect of Tarisa on collaboration, it has not considered how Tarsia may complement the application of communication, creativity, critical thinking and academic performance. It is recommended that the future study may discover the effect of Tarsia, or other active learning teaching techniques on the above mentioned attributes.

\section{References}

Ananiadou, K. and Claro, M. (2009). $21^{\text {st }}$ Century Skills and Competences for New Millennium Learners in OECD Countries, OECD Education Working Papers, No. 41, OECD Publishing. http://dx.doi.org/10.1787.218525261154

Csikszentmihályi, M. (1990). Flow: The Psychology of Optimal Experience. Harper Perennial, London.

Fwu, B. J., \& Wang, H. H. (2006). Practice makes perfect on the blackboard: A cultural analysis of mathematics instructional patterns in Taiwan. ZDM, 38(5), 368-375.

Hermitech Laboratory (n.d.). Information on Formulator Tarsia. Retrieved from http://www.mmlsoft.com/index.php/products/tarsia

Kivunja, C. (2014). Innovative Pedagogies in Higher Education to Become Effective Teachers of 21 st Century Skills: Unpacking the Learning and Innovations Skills Domain of the New Learning Paradigm. International Journal of Higher Education, 3(4), 37-48.

Marjan Laal \& Seyed Mohammad Ghodsi (2011). Benefits of collaborative learning. Procedia - Social and Behavioral Sciences 31, 486 - 490.

NEA. (2014). Preparing $21^{\text {st }}$ century students for a global society: An educators guide to the "Four Cs"". National Education Association. Retreived from http://ww.nea.org/assets/docs/A-Guide-to-Four-Cs.pdf on 26 August 2014.

Roh, K. H. (2003). Problem-based learning in mathematics. ERIC Clearinghouse.

So, H., \& Brush, T. A. (2008). Student perceptions of collaborative learning, social presence and satisfaction in a blended learning environment: Relationships and critical factors. Computers \& Education, 51(1), 318336.

Sorden, S. D. (2011). Relationships among collaborative learning, social presence and student satisfaction in a blended learning environment. Unpublished doctoral dissertation). Northern Arizona University, Arizona, USA.

Watson, A., \& Mason, J. (2004). The exercise as mathematical object: Dimensions of possible variation in practice. In Proc. 24th Conf. of The British Society of Research in Learning Mathematics (Vol. 2, pp. 107. 112).

\section{Appendix: Quantitative Instrument}

The collaborative learning, social presence, and satisfaction (CLSS) questionnaire (So \& Brush, 2008).

Likert Scale:

\author{
1 Strongly Disagree \\ 2 Disagree \\ 3 Neutral \\ 4 Agree \\ 5 Strongly Agree
}

Questions

1. I felt part of a learning community in my group. 12345

2. I actively exchanged my ideas with group members. 12345

3. I was able to develop new skills and knowledge from other members in my group. 12345

4. I was able to develop problem solving skills through peer collaboration. 12345

5. Collaborative learning in my group was effective. 12345

6. Collaborative learning in my group was time consuming. 12345

7. Overall, I am satisfied with my collaborative learning experience in this course. 12345 